\title{
Correction to: L_RNA_scaffolder: scaffolding genomes with transcripts
}

Wei Xue ${ }^{1,2,3 \dagger}$, Jiong-Tang Li ${ }^{{ }^{*}+}$, Ya-Ping Zhu ${ }^{1,2}$, Guang-Yuan Hou' ${ }^{1}$ Xiang-Fei Kong ${ }^{1,2}$, You-Yi Kuang ${ }^{4}$ and Xiao-Wen Sun $^{1 *}$

\section{Correction to: BMC Genomics https://doi.org/10.1186/1471-2164-14-604}

Following the publication of this article [1], the authors reported that the link to the software described in the article is no longer valid. They have therefore provided the following alternative address in this Correction article in order to gain access to the software: https:// github.com/CAFS-bioinformatics/L_RNA_scaffolder

\begin{abstract}
Author details
'The Centre for Applied Aquatic Genomics, Chinese Academy of Fishery Sciences, Beijing 100141, China. ${ }^{2}$ College of Fisheries and Life Science, Shanghai Ocean University, Shanghai 201306, China. ${ }^{3}$ Key Laboratory of Computational Biology, CAS-MPG Partner Institute for Computational Biology, Shanghai Institutes for Biological Sciences, Chinese Academy of Sciences, Shanghai 200031, China. ${ }^{4}$ Heilongjiang River Fisheries Research Institute, Chinese Academy of Fishery Sciences, Harbin 150001, China.
\end{abstract}

Received: 29 May 2019 Accepted: 29 May 2019

Published online: 07 June 2019

\section{Reference}

1. Xue, et al. L_RNA_scaffolder: scaffolding genomes with transcripts. BMC Genomics. 2013;14:604. https://doi.org/10.1186/1471-2164-14-604.

\footnotetext{
*Correspondence: lijt83@gmail.com; sunxw2002@163.com

${ }^{+}$Wei Xue and Jiong-Tang Li contributed equally to this work.

'The Centre for Applied Aquatic Genomics, Chinese Academy of Fishery

Sciences, Beijing 100141, China

Full list of author information is available at the end of the article
}

(c) The Author(s). 2019 Open Access This article is distributed under the terms of the Creative Commons Attribution 4.0 International License (http://creativecommons.org/licenses/by/4.0/), which permits unrestricted use, distribution, and reproduction in any medium, provided you give appropriate credit to the original author(s) and the source, provide a link to the Creative Commons license, and indicate if changes were made. The Creative Commons Public Domain Dedication waiver (http://creativecommons.org/publicdomain/zero/1.0/) applies to the data made available in this article, unless otherwise stated. 